\section{Dicionário Crítico do Feminismo}

Orgs.: Hirata, Laborie, Doaré e Senotier São Paulo, Editora Unesp, 2009, 341 p.

\section{Claudia Mazzei Nogueira*}

\section{O Dicionário crítico do feminismo foi} lançado no Brasil no fim do ano de 2009, pela Editora da Unesp, nove anos depois da edição francesa. É organizado por Helena Hirata, Françoise Laborie, Hélène Le Doaré e Danièle Senotier, trazendo 48 verbetes sobre temas da maior importância para pesquisadoras, militantes, estudantes, mulheres, homens, que se interessam em desvendar mais sobre o tema das relações de gênero.

Essa publicação contempla, em suas páginas, as mais diversas análises categoriais que vão desde a reflexão sobre aborto e contracepção (Alisa Del Re) até a violência (Carme Alemany). Na edição brasileira, em relação à $1^{\text {a }}$ edição francesa, foram incluídos mais dois verbetes: "Emprego", escrito por Margaret Maruani, e

\footnotetext{
* Professora do Departamento de Serviço Social — DSS, do Centro Socioeconômico - CSE, da Universidade Federal de Santa Catarina - UFSC - Florianópolis/SC, Brasil. Autora dos livros A feminização no mundo do trabalho, Editora Autores Associados, 2004 e $O$ trabalho duplicado, Editora Expressão Popular, 2005.E-mail: mazzeinogueira@uol.com.br.
}

"Lesbianismo", escrito por Jules-France Falquet, alterando o número de 46 para 48 verbetes, o que torna essa edição, de certa forma, mais completa.

Mas há algo importante para ser destacado no Dicionário: existe uma centralidade na questão do trabalho que, em grande medida, se encontra presente na maioria dos verbetes. Com isso, fica explícito que a preocupação analítica das(os) autoras(es) é vincular a compreensão das relações sociais de sexo/gênero com essa centralidade. Neste sentido, tudo indica que os verbetes contidos no Dicionário foram desenvolvidos por pesquisadores/ militantes pertencentes a uma vertente crítica.

Outra preocupação presente nessa bela publicação é certamente favorecer e propiciar uma leitura, com clara direção reflexiva, apreendendo as perspectivas teóricas, políticas e até mesmo econômicas que envolvem o feminismo.

Para tanto, o Dicionário se encontra dividido, mesmo que não explicitamente, em três grandes grupos: o primeiro com pelo menos dezesseis verbetes ligados diretamente ao mundo do trabalho, entre eles: desemprego; emprego, trabalho; divisão sexual do trabalho (este sendo em nosso entendimento, um conceito-chave para as análises acerca da questão de gênero) etc. O segundo grupo, com um viés mais político e econômico, contemplando aproximadamente quinze verbetes: cidadania, aborto e contracepção, movimentos sociais; público/privado, movimentos feministas, universalismo e particularismo etc. E o terceiro e último, o grupo de ver- 
betes mais voltados para a psicologia, educação e outros temas sociais, como, por exemplo: lesbianismo; violência; educação e socialização; religiões etc.

Um dos pontos fortes da publicação brasileira é o verbete sobre emprego, escrito por Maruani, que traz uma reflexão analítica sobre emprego e trabalho. Afirma a autora que "a oferta de trabalho é oriunda dos indivíduos e a oferta de emprego, das empresas". Define também, de forma clara, a diferença entre trabalho e emprego. Em relação ao trabalho, trata-se de uma "atividade de produção de bens e serviços, assim como conjunto das condições de exercício dessa atividade", e emprego é o "conjunto das modalidades de entrada e saída do mercado de trabalho, assim como a tradução da atividade laboriosa em termos de estatuto social". E, complementa, "emprego não é uma 'questão social' entre outras. Na realidade, trata-se de um dos elementos estruturantes do funcionamento da sociedade, um dos elementos que dão sentido a outros desafios sociais".

Ainda frente a essa questão de trabalho e emprego, Maruani indica que "o acesso ao emprego contribui fortemente para a construção das hierarquias sociais, para a produção de mecanismos de diferenciação, classificação e segregação", categorias essas fundamentais para pesquisadoras(es) do mundo do trabalho, principalmente aquelas(es) que estarão priorizando a desigualdade entre as forças de trabalho femininas e masculinas, presentes na complexa e contraditória relação capital/trabalho.

A autora ainda lembra que "ter um emprego significa ter trabalho e salário, mas significa também ter um espaço na sociedade". Aqui, mesmo que indiretamente, fica evidente a centralidade do trabalho, ou, para lembrar Lukács, trabalho como protoforma do ser social.

E a pesquisadora vai mais além. Em suas palavras, "analisar a situação das mulheres no mercado de trabalho é questionar seu estatuto social: o emprego é um fio condutor para compreender o espaço das mulheres na sociedade", e, podemos complementar, o espaço desigual das mulheres na sociedade.

Embora tenhamos diferenças dentro do campo sociológico, principalmente aquele que fragmenta, criando dicotomicamente, por exemplo, a sociologia do trabalho e a sociologia do emprego, o âmago das análises é por nós compartilhado e merece atenção especial do(a) leitor(a) brasileiro(a), ainda que a realidade analisada seja a francesa.

Aliás, como lembra Lucila Scavone, em seu prefácio à edição brasileira, ao se referir a um ponto de ligação entre o feminismo brasileiro e o francês, afirma que "nos anos da ditadura militar no Brasil, a França acolheu exiladas políticas e estudantes que criaram, em 1976, 'O Círculo de Mulheres Brasileiras em Paris"', o qual discutia as questões referentes a gênero, ou nos termos de determinada escola francesa, as relações de sexo. No começo dos anos 1980, muitas das militantes que compunham o Círculo retornaram ao Brasil com essa experiência europeia acumulada. Esse fato foi primordial para o fortalecimento dos movimentos feministas no país, 
principalmente no que tange à luta por direitos sociais.

Portanto, a publicação do Dicionário crítico do feminismo, ainda que tenha sua raiz na experiência francesa, é indubitavelmente importante, tanto pela qualidade das pesquisadoras que organizam esse volume, quanto pela excelência das autoras e autores dos verbetes nele presentes.

De certa forma, o Dicionário vem ocupar uma lacuna bibliográfica na língua portuguesa para todas e todos que pesquisam, estudam ou simplesmente têm interesse na temática sobre o feminismo. Assim, só nos resta parabenizar a iniciativa e desejar uma bela viagem reflexiva, através dessa prazerosa leitura do Dicionário crítico do feminismo.

Artigo recebido em jun./2010

Aprovado em dez./2010 